\title{
Pengaruh Koneksi Politik terhadap Penghindaran Pajak
}

\author{
Nabila Khoirunnisa Asadanie ${ }^{1)}$, Lintang Venusita ${ }^{2)}$ \\ ${ }^{1}$ Prodi S1 Akuntansi, Universitas Negeri Surabaya, Indonesia. \\ email: nabilaasadanie@mhs.unesa.ac.id \\ ${ }^{2}$ Prodi S1 Akuntansi, Universitas Negeri Surabaya, Indonesia. \\ email: $\underline{\text { venusita@gmail.com }}$
}

\begin{abstract}
This study aims to examine the effect of political connection on tax avoidance. The sample in this study were manufacture companies from the BEI for the periode 2015-2017. The sample were selected using purposive sampling technique and obtained a sample of 55 companies. The analysis technique used in this study is multiple linear regressions analysis using IBM SPSS Statistic program 23. The result of the study show that political connection has a negative effect on tax avoidance. Keywords: political connection, tax avoidance.
\end{abstract}

Abstrak

Penelitian ini bertujuan untuk menguji pengaruh koneksi politik terhadap penghindaran pajak. Sampel dalam penelitian ini adalah perusahaan manufaktur yang terdaftar di BEI periode 20152017. Sampel dipilih menggunakan teknik purposive sampling dan diperoleh 55 perusahaan. Teknik analisis yang digunakan dalam penelitian ini adalah analisis regresi linear berganda menggunakan program IBM SPSS Statistik 23. Hasil penelitian menunjukkan bahwa koneksi politik berpengaruh negatif terhadap penghindaran pajak.

Kata Kunci: koneksi politik, penghindaran pajak

\section{PENDAHULUAN}

Sebagai negara berkembang, Negara Indonesia melakukan pembangunan dalam berbagai aspek. Dalam melaksanakan pembangunan, tentunya pemerintah Indonesia memerlukan dukungan dana yang besar. Dana yang digunakan untuk pembangunan tersebut dapat diperoleh dari berbagai sumber, salah satu sumber tersebut adalah berasal dari pajak. Peran pajak dalam menyumbang penerimaan negara semakin besar dan signifikan, hal ini dapat dilihat dari terus meningkatnya pendapatan negara dari sektor pajak yang tergambar dalam APBN, yang selanjutnya akan digunakan untuk membiayai penyelenggaraan pembangunan dan biaya rutin negara (Pohan, 2016:2).

Data dari Badan Pusat Statistik menyebutkan bahwa penerimaan pajak pada 2017 mencapai 85,6\% sedangkan 14,3\% dari Penerimaan Negara Bukan Pajak dan $0,1 \%$ berasal dari hibah. Namun realisasi penerimaan pajak selalu tidak mencapai target. Kinerja penerimaan pajak yang kurang dibuktikan dengan angka tax ratio Indonesia yang tergolong rendah. Perusahaan yang merupakan wajib pajak badan berusaha untuk membayar pajak serendah mungkin baik dengan cara legal ataupun ilegal sehingga laba perusahaan dapat dicapai dengan maksimal karena pembayaran pajak dapat mengurangi laba bersih perusahaan. Salah satu bentuk perlawanan wajib pajak secara legal adalah dengan melakukan penghindaran pajak (tax avoidance).

Beberapa kasus penghindaran pajak dilakukan oleh perusahaan seperti pada kasus penghindaran pajak Asian Agri. Asian Agri adalah perusahaan manufaktur yang bergerak sebagai produsen minyak kelapa sawit. Asian Agri merupakan anak usaha Royal Golden Eagle International (RGEI) yang dimiliki Sukanto Tanoto. Dikutip dari Kontan (2007) Asian Agri melakukan penyimpangan pajak dari 14 perusahaan yang tergabung di dalamnya sebesar Rp 1,2 triliun. Sukanto Tanoto pemilik Royal Golden Eagle International (RGEI) yang membawahi Grup Asian 
Agri diketahui mempunyai kedekatan dengan Presiden Soeharto, Presiden Megawati Soekarno Putri serta Presiden Susilo Bambang Yudhoyono.

Kasus selanjutnya adalah kasus dari Grup Bakrie. Direktur Jenderal Pajak Mochamad Tjiptardjo mengungkapkan kurang bayar pajak dari tiga perusahaan milik Grup Bakrie yaitu PT Kaltim Prima Coal, PT Bumi Resources, dan PT Arutmin, masing-masing Rp 1,5 triliun untuk KPC, Rp 376 miliar untuk Bumi, dan US\$ 39 juta untuk Arutmin.

Grup Bakrie adalah perusahaan yang dirintis Keluarga Bakrie dan identik dengan Aburizal Bakrie yang pernah menjabat menjadi ketua umum Partai Golkar dan pernah menjabat sebagai Menteri Koordinator Perekonomian meski kemudian digeser menjadi Menteri Koordinator Kesejahteraan.

Dari beberapa kasus diatas, dapat dilihat bahwa perusahaan-perusahaan tersebut mempunyai koneksi politik. Koneksi politik yang digunakan perusahaan sering dimanfaatkan perusahaan untuk memperoleh keuntungan bisnis dengan memanfaatkan koneksi politiknya. Perusahaan yang memiliki koneksi politik adalah perusahaan yang mempunyai kaitan dengan pemerintah ataupun dengan politik. Perusahaan berkoneksi politik melakukan penghindaran pajak dengan menjadikan koneksi politik yang dimiliki oleh anggota perusahaan sebagai jalan pintas dalam mencari keuntungan untuk perusahaan.

\section{KAJIAN TEORI DAN PENGEMBANGAN HIPOTESA Upper Echelon Theory}

Upper Echelon Theory adalah suatu teori yang menganggap manajemen puncak sebagai pembuat keputusan strategi yang utama di dalam organisasi. Sehingga keputusan strategi yang dibuat pemimpin memiliki dampak secara langsung terhadap hasil organisasi. Upper echelon perspective dapat diidentifikasikan pada latar belakang yang tampak dari manajer atas seperti usia, pengalaman, pendidikan, latar belakang sosial, kondisi ekonomi, dan karakteristik kelompok sekitarnya. Manajemen puncak (komisaris dan direksi) yang memiliki latar belakang sosial dan karakteristik kelompok yang terdapat koneksi politik akan berani mengambil keputusan yang lebih berisiko karena di dukung oleh koneksi politiknya sehingga cenderung memilih untuk melakukan penghindaran pajak dengan tujuan keuntungan perusahaan.

\section{Koneksi Politik}

Menurut Gomez \& Jomo (2009) dalam Pranoto \& Widagdo (2015), perusahaan yang mempunyai koneksi politik merupakan perusahaan atau konglomerat yang mempunyai hubungan dekat dengan pemerintah.

Perusahaan yang mempunyai hubungan dekat dengan pemerintah dapat diartikan sebagai perusahaan milik pemerintah, yaitu perusahaan yang berbentuk BUMN atau BUMD. Konglomerat (pemilik) yang mempunyai hubungan dekat dengan pemerintah adalah konglomerat atau pemilik perusahaan yang merupakan tokoh politik terkemuka. Tokoh politik tersebut merupakan anggota atau mantan anggota dewan di pemerintahan pusat atau militer.

\section{Penghindaran Pajak}

Suandy (2006:14) menjelaskan penghindaran pajak atau tax avoidance sebagai suatu aktivitas pengurangan beban pajak secara legal yang dilakukan dengan cara memanfaatkan peraturan-peraturan perpajakan secara optimal dan kelemahankelemahan yang ada dalam peraturan perpajakan. 


\section{METODE PENELITIAN}

Menurut Sugiyono (2016:7) teknik analisis data yang digunakan dalam penelitian kuantitatif menggunakan statistik. Penelitian ini menggunakan analisis statistik deskriptif dan analisis regresi untuk menganalisis pengaruh variabel independen (koneksi politik) terhadap variabel dependen (penghindaran pajak). Populasi merupakan wilayah generalisasi yang terdiri atas obyek/ subyek yang mempunyai kualitas dan karakteristik tertentu yang ditetapkan oleh peneliti untuk dipelajari dan kemudian ditarik kesimpulannya (Sugiyono 2016:80). Populasi dalam penelitian ini adalah seluruh perusahaan manufaktur yang terdaftar di BEI mulai tahun 2015-2017.

Data yang digunakan dalam penelitian ini merupakan data kuantitatif karena data penelitian berupa angka-angka dan dianalisis menggunakan statistik (Sugiyono, 2016:7). Sumber data yang dipakai adalah data sekunder yang diperoleh dari sumber yang sudah ada, berupa laporan keuangan dan laporan tahunan perusahaan manufaktur tahun 2015-2017. Sumber data diperoleh dari website resmi Bursa Efek Indonesia (BEI) yaitu www.idx.co.id.

Teknik pengumpulan data dalam penelitian ini adalah teknik dokumentasi dan studi kepustakaan. Teknik dokumentasi dilakukan dengan cara mengumpulkan data informasi yang dibutuhkan dari Bursa Efek Indonesia (BEI) berupa laporan keuangan dan laporan tahunan perusahaan manufaktur 2015-2017 yang dipublikasikan pada situs www.idx.com. Teknik selanjutnya yaitu studi kepustakaan dilakukan membaca, mempelajari literatur dan publikasi yang berhubungan dengan penelitian. Menurut Sugiyono (2016:7) teknik analisis data yang digunakan dalam penelitian kuantitatif menggunakan statistik. Penelitian ini menggunakan analisis statistik deskriptif dan analisis regresi linier berganda.

\section{HASIL DAN PEMBAHASAN}

Tabel 1. Hasil Pengujian Statistic Deskriptif Descriptive Statistics

\begin{tabular}{|c|c|c|c|c|c|}
\hline & \multicolumn{3}{|c|}{ Descriptive Statistics } & \multirow[b]{2}{*}{ Mean } & \multirow{2}{*}{$\begin{array}{c}\text { Std. } \\
\text { Deviation }\end{array}$} \\
\hline & $\mathrm{N}$ & Min. & Max. & & \\
\hline KPOL & 147 &, 00 & 1,00 &, 38 &, 4889 \\
\hline SIZE & 147 & 20,66 & 33,19 & 28,44 & 1,9569 \\
\hline ROE & 147 & ,0010 & 1,35 &, 18 & 2503 \\
\hline ETR & 147 &, 05 & ,59 & ,26 & 0905 \\
\hline Valid N (listwise) & 147 & & & & \\
\hline
\end{tabular}

\section{Koneksi Politik}

Variabel independen koneksi politik menghasilkan nilai terendah 0 dan nilai tertinggi 1 . Nilai tersebut didapat dari variabel dummy yaitu nilai 0 jika perusahaan tidak memiliki koneksi politik dan nilai 1 jika perusahaan memiliki koneksi politik. Nilai rata- rata dari variabel koneksi politik sebesar 0,3878 dan standar deviasi sebesar 0,4888 .

\section{Ukuran Perusahaan}

Variabel kontrol ukuran perusahaan yang diproksikan dengan logartitma natural dari total aset memiliki nilai rata-rata 28,2893 dan standar deviasi 2,1414. Nilai tertinggi variabel ini sebesar 33,1988 dan nilai terendah sebesar 18,6703.

\section{Profitabilitas}

Profitabilitas yang diproksikan dengan ROE (Return On Equity) memiliki nilai rata-rata 0,1708 dan standar deviasi 0,2409 . Nilai tertinggi sebesar 1,3585 dan nilai terendah sebesar 0,0006 . 


\section{Penghindaran Pajak}

Variabel dependen yaitu penghindaran pajak yang diproksikan dengan ETR memiliki nilai rata-rata sebesar 0,2859 atau $28 \%$ dan untuk standar deviasinya yaitu sebesar 0,1386 atau sebesar 14\%. Nilai tertinggi variabel ini sebesar 0,9219 atau sebesar $92 \%$ kemudian untuk nilai terendah yaitu sebesar 0,0052 atau sebesar $0,52 \%$.

Tabel 2. Hasil Uji Kolmogorov-Smirnov Test

\begin{tabular}{llr}
\hline & & Unstd. Residual \\
\hline $\mathrm{N}$ & & 133 \\
Normal Parameters & \\
& Mean &,- 0263 \\
Most Extreme & Std. Deviation &, 0514 \\
Differences & Absolute &, 068 \\
& Positive &, 068 \\
Test Statistic & Negative &,- 051 \\
Asymp. Sig. (2-tailed) &, 068 \\
\multicolumn{2}{c}{ Sumber: Output SPSS versi 23} &, $200^{\mathrm{c}, \mathrm{d}}$ \\
\hline
\end{tabular}

\begin{tabular}{clrr}
\multicolumn{3}{c}{ Tabel 3. Hasil Uji Multikolinieritas } \\
\hline Model & \multicolumn{2}{c}{ Collinearity } & Statistics \\
& (Constant) & Tolerance & VIF \\
\hline $\mathbf{1}$ & KPOL &, 813 & 1,230 \\
& SIZE &, 857 & 1,167 \\
& ROE &, 884 & 1,132
\end{tabular}

\begin{tabular}{cccccc}
\multicolumn{5}{c}{ Sumber: Output SPSS versi 23} & \\
Tabel 4. Hasil Uji Autokorelasi & \\
\hline Model & $\mathrm{R}$ & R Square & $\begin{array}{c}\text { Adjusted R } \\
\text { Square }\end{array}$ & Std. Error & $\begin{array}{c}\text { Durbin } \\
\text { Watson }\end{array}$ \\
\hline 1 &, $330^{\mathrm{a}}$ &, 109 &, 088 &, 04813514 & 2,164
\end{tabular}

Sumber: Output SPSS versi 23

Dalam penelitian ini uji normalitas dilakukan dengan menggunakan uji statistik non-parametrik one sample Kolmogorov-Sminrnov. Uji normalitas untuk menguji normalitas dari variabel penganggu atau residual dalam model regresi pada penelitian ini. Dasar pengambilan keputusan adalah data terdistribusi secara normal apabila nilai Asymp. Sig. (2-tailed) atau nilai signifikansi lebih besar dari 0,05.Pada tabel hasil uji normalitas menggunakan Uji Kolmogorov-Smirnov menunjukkan nilai Asymp. Sig. (2-tailed) sebesar 0,200 sehingga nilainya lebih besar dari 0,05, maka dapat dinyatakan bahwa data terdistribusi secara normal dan memenuhi uji normalitas.

Tabel 3 menunjukkan hasil uji multikolinearitas dengan nilai VIF secara keseluruhan memiliki nilai dibawah 10,00 atau $>1$ dan nilai tolerance secara keseluruhan juga berada pada nilai $<1$ atau $>0,1$ sehingga dapat disimpulkan bahwa secara keseluruhan model regresi terbukti bebas dari multikolinearitas. Pada tabel 4 dapat dilihat bahwa nilai d sebesar 2,164. Pada penelitian ini jumlah $\mathrm{k}=4$ dan $\mathrm{N}=141$ sehingga nilai du sebesar 1,7631. Hal ini menunjukkan bahwa nilai du lebih kecil dari nilai d, dan d lebih kecil dari 4- du. Artinya tidak ditemukan adanya autokorelasi pada model regresi.

Tabel 5 Hasil Uji Heterokedastisitas

\begin{tabular}{lrrrr}
\hline Model & $\mathrm{R}$ & R Square & $\begin{array}{c}\text { Adjusted R } \\
\text { Square }\end{array}$ & $\begin{array}{l}\text { Std. Error of } \\
\text { the Estimate }\end{array}$ \\
\hline 1 &, $277^{\mathrm{a}}$ &, 077 &, 033 &, 00431 \\
\hline \multicolumn{4}{c}{ Sumber: Ouput SPSS versi 23}
\end{tabular}


Sedangkan hasil dari uji heterokedastisitas dalam model regresi dapat dilihat pada tabel 5 dimana nilai R Square pada tabel Model Summary sebesar 0,077. Nilai $\mathrm{c}^{2}$ hitung diperoleh dengan cara mengalikan nilai $\mathrm{R}$ Square dengan total sampel ( $\mathrm{n}=133$ ) yang didapat hasilnya adalah 10,241 . Nilai $\mathrm{c}^{2}$ tabel dengan signifikansi sebesar 0,05 sebesar 160,915. Hasil tersebut menunjukkan bahwa $\mathrm{c}^{2}$ hitung $<\mathrm{c}^{2}$ tabel yaitu $10,241<160,915$. Sehingga dapat disimpulkan bahwa model regresi terbebas dari adanya heterokedastisitas.

Tabel 6 Hasil Uji Koefisien Determinasi

\begin{tabular}{lrrrrr}
\hline Model & $\mathrm{R}$ & \multicolumn{2}{c}{ R Square } & $\begin{array}{c}\text { Adjusted R } \\
\text { Square }\end{array}$ & $\begin{array}{c}\text { Std. Error of the } \\
\text { Estimate }\end{array}$ \\
\hline 1 &, $330^{\mathrm{a}}$ &, 109 & &, 088 &, 04813514 \\
\hline Sumber: Ouput SPSS versi 23 & & & &
\end{tabular}

Tabel 6 menunjukkan hasil uji koefisien determinasi dengan hasil uji yaitu nilai adjusted $\mathrm{R}$ square pada model penelitian sebesar 0,088 . Artinya adalah sebesar $8,8 \%$ variasi dari variabel dependen penghindaran pajak mampu dijelaskan oleh variabel independen koneksi politik bersama dengan dua variabel kontrol yaitu ukuran perusahaan dan profitabilitas, sedangkan sisanya yaitu $91,2 \%$ dijelaskan oleh variabel lain diluar penelitian ini.

\section{Tabel 7 Uji Statistik F (Uji Simultan)}

\begin{tabular}{|c|c|c|c|c|c|}
\hline Model & $\begin{array}{l}\text { Sum of } \\
\text { Squares }\end{array}$ & df & Mean Square & $\mathrm{F}$ & Sig. \\
\hline 1 Regression & ,037 & 3 & ,012 & 5,267 &, $002^{\mathrm{b}}$ \\
\hline Residual & 299 & 129 & ,002 & & \\
\hline Total & ,336 & 132 & & & \\
\hline
\end{tabular}

Tabel 7 pada hasil uji $\mathrm{F}$ (uji simultan) menunjukkan nilai signifikansi sebesar 0,002 yang mana kurang dari 0,05 sehingga dapat disimpulkan bahwa pada model regresi, variabel independen mampu memprediksi variabel dependen atau koneksi politik berpengaruh terhadap penghindaran pajak.

Tabel 8 Uji Statistik t

\begin{tabular}{|c|c|c|c|c|c|c|}
\hline \multirow{2}{*}{\multicolumn{2}{|c|}{ Model }} & \multicolumn{2}{|c|}{ Unstd. Coefficients } & \multirow{2}{*}{$\begin{array}{c}\text { Std. } \\
\text { Coefficients } \\
\text { Beta }\end{array}$} & \multirow[b]{2}{*}{$\mathrm{t}$} & \multirow[b]{2}{*}{ Sig. } \\
\hline & & $\mathrm{B}$ & Std. Error & & & \\
\hline 1 & (Constant) & ,309 & ,063 & & 4,928 & ,000 \\
\hline & KPOL &,- 031 & ,009 &,- 306 & $-3,324$ & 001 \\
\hline & SIZE &,- 001 & ,002 &,- 055 &,- 617 &, 539 \\
\hline & ROE & ,000 & ,018 &,- 001 &,- 006 & ,995 \\
\hline
\end{tabular}

Berdasarkan hasil uji statistik t untuk meilihat pengaruh koneksi politik terhadap penghindaran pajak, hasilnya adalah koneksi politik berpengaruh negatif terhadap ETR. Sehingga hipotesis penelitian yang menyatakan koneksi politik berpengaruh positif terhadap penghindaran pajak diterima. Sedangkan variabel kontrol yaitu ukuran perusahaan dan profitabilitas menunjukkan hasil tidak berpengaruh dengan nilai signifikansi 0,539 dan 0,995 yang lebih besar dari 0,05.

\section{HASIL DAN PEMBAHASAN}

Hipotesis diterima, menyatakan bahwa koneksi politik berpengaruh positif terhadap penghindaran pajak yang diproksikan dengan ETR. Variabel koneksi politik menunjukkan nilai koefisien regresi sebesar -0,31 dan nilai signifikansi sebesar 0,001. Nilai koefisien tersebut mengindikasikan hubungan negatif antara koneksi politik dengan penghindaran pajak yang diproksikan dengan ETR. Sehingga semakin tinggi koneksi politik maka akan semakin rendah nilai ETR yang 
mengartikan semakin tinggi koneksi politik pada perusahaan maka semakin tinggi penghindaran pajak yang dilakukan oleh perusahaan. Hal ini dikarenakan intepretasi ETR yang berbanding terbalik dengan penghindaran pajak.

Koneksi politik yang ada dalam perusahaan dapat membuat perusahaan memiliki perlakuan khusus, seperti kemudahan dalam memperoleh pinjaman modal dan resiko pemeriksaan pajak rendah yang membuat perusahaan semakin menghindari pajak (Suandy, 2000:2). Koneksi politik yang dimiliki perusahaan juga dimanfaatkan dengan adanya lobi-lobi yang bersifat menekan otoritas pajak untuk mengurangi jumlah pajak yang dibayar maupun untuk memperkecil punishment apabila metode penghindaran pajak yang dilakukan terungkap karena melanggar aturan perpajakan (Ferdiawan \& Firmansyah, 2017).

Hasil penelitian ini mendukung riset yang dilakukan oleh Adhikari et al., (2006) yang menunjukkan bahwa koneksi politik memiliki pengaruh negatif terhadap ETR. Perusahaan yang memiliki hubungan politik dengan pemerintah Malaysia terbukti membayar pajak lebih rendah secara signifikan. Di Indonesia, Sudibyo \& Jianfu (2016) dan Ferdiawan \& Firmansyah (2017) yang hasil risetnya menunjukkan perusahaan yang mempunyai koneksi politik mampu membayar pajak lebih rendah dibanding perusahaan yang tidak mempunyai koneksi politik.

\section{KESIMPULAN DAN SARAN \\ Kesimpulan}

Berdasarkan hasil pengujian dan analisis penelitian yang telah dilakukan dapat disimpulkan semakin tinggi koneksi politik maka akan semakin rendah nilai ETR yang mengartikan semakin tinggi koneksi politik pada perusahaan maka semakin tinggi penghindaran pajak yang dilakukan oleh perusahaan. Hal ini dikarenakan intepretasi ETR yang berbanding terbalik dengan penghindaran pajak. Koneksi politik yang ada dalam perusahaan dapat membuat perusahaan memiliki perlakuan khusus, seperti kemudahan dalam memperoleh pinjaman modal, resiko pemeriksaan pajak rendah yang membuat perusahaan semakin menghindari pajak.

\section{Saran}

Berdasarkan kesimpulan yang telah dipaparkan diatas, saran yang dapat diberikan adalah agar penelitian selanjutnya lebih meluaskan sampel penelitian keseluruh perusahaan yang ada dalam Bursa Efek Indonesia agar dapat melihat secara luas pengaruh koneksi politik terhadap penghindaran pajak. Penelitian selanjutnya juga diharapkan memiliki rentang waktu yang lebih lama sehingga dapat mengetahui penghindaran pajak yang dilakukan perusahaan dalam kurun waktu yang lebih luas. Penelitian selanjutnya juga diharapkan dapat menambah proksi dari koneksi politik sehingga tidak terbatas pada direksi dan dewan dewan komisaris.

\section{DAFTAR PUSTAKA}

Adhikari, A., Derashid, C., \& Zhang, H. (2006). Public Policy , Political Connections, and Effective Tax Rates: Longitudinal Evidence from Malaysia. Journal of Accounting and Public Policy, 25, 574-595.

Agustino, L. (2007). Perihal Politik: Sebuah Bahasan Memahami Ilmu Politik. Yogyakarta: Graha Ilmu.

Aliani, K. (2014). CEO Characteristics and Corporate Tax Planning Evidence from

US Companies Khaoula Aliani. International Journal Managerial and Financial Accounting, 6(1).

Chen, D., \& Zheng, Y. (2013). CEO Tenure and Risk-Taking. SSRN Electronic 


\section{Journal.}

Chen, Z., Dyreng, S. D., \& Li, B. (2015). Corporate Political Contributions and Tax Avoidance. Paper Presented at the 2014 American Taxation Association Midyear Meeting., 1-48.

Duan, T., \& Zhang, J. Z. (2018). The Burden Of Attention: CEO Publicity and Tax Avoidance. Journal of Business Research, 87, 90-101.

Faccio, M. (2002). Politically- connected firms: Can They Squeeze the State? The American Economic Review 96(1), (219), 369-386.

Faccio, M. (2006). American Economic Association Politically Connected Firms. Source: The American Economic Review, 96(1), 369-386.

Francis, B. B., Hasan, I., Sun, X., \& Wu, Q. (2016). CEO Political Preference and Corporate Tax Sheltering. Journal of Corporate Finance, 38, 3753.https://doi.org/10.1016/j.jcorpfin.2016.03.003

Ghozali, I. (2016). Aplikasi Analisis Multivariate dengan IBM SPSS 23 (Edisi 8). In Semarang: UNDIP.

Hambrick, D. C., \& Mason, P. A. (1984). Upper Echelons: The Organization as a Reflection of its Top Managers. Academy of Management Review, 9(2), 193206.

Hanlon, M., \& Heitzman, S. (2010). A Review of Tax Research. Journal of Accounting and Economics, 50(2-3), 127-178. https://doi.org/10.1016/j.jacceco.2010.09.002

Hijriani, A. N., Latifah, S. W., \& Setyawan, S. (2014). Komisaris dan Karakteristik Perusahaan terhadap Penghindaran Pajak ( Perusahaan BUMN Yang Terdaftar di Bursa Efek Indonesia ). Jurnal Reviu Akuntansi Dan Keuangan, 4(1), 525534.

International, T. (2007). Transparency International Indonesia. Retrieve from https://www.transparency.org/country/IDN

Kasmir. (2009). Pengantar Manajemen Keuangan (Kedua). Jakarta: Prenada Media Group.

Kemenkeu. (2017). Perekonomian Indonesia dan APBN 2017. Retrieved from https://www.kemenkeu.go.id/apbn2017

Kemenkeu. (2018). APBN KITA (Kinerja dan Fakta). Retrieved from https://www.kemenkeu.go.id/media/6890/apbn-kita-edisi-januari-2018.pdf

Kim, C., \& Zhang, L. (2014). Corporate Political Connections and Tax Aggressiveness. Contemporary Accounting Research, Forthcoming, 33(1), 78-114. https://doi.org/10.1111/1911-3846.12150

Kompas. (2009). Ditjen Pajak Selidiki Tunggakan Pajak Bakrie. Retrieved from https://nasional.kompas.com/read/2009/12/16/13062669/ditjen.pajak.selidiki. tunggakan.pajak.bakrie

Kontan, H. (2007). Inilah Delapan Tersangka Kasus Pajak Asian Agri. Retrieved February 10, 2019, from https://www.ortax.org/ortax/?mod=berita\&page=show\&id=559\&q=\&hlm=8 46

Lanis, R., \& Richardson, G. (2012). Corporate Social Responsibility and Tax Aggressiveness: An Empirical Analysis. Journal of Accounting and Public Policy, 31(1), 86-108. https://doi.org/10.1016/j.jaccpubpol.2011.10.006

Leuz, C., \& Oberholzer-gee, F. (2006). Political Relationships , Global Financing, and Corporate Transparency: Evidence from Indonesia, 81, 411-439. https://doi.org/10.1016/j.jfineco.2005.06.006

Pohan, C. A. (2016). Manajemen Perpajakan Strategi Perencanaan Pajak dan 
Bisnis (Revisi). Jakarta: PT

Gramedia.

Pranoto, B., \& Widagdo, A. (2015). Pengaruh Koneksi Politik Dan Corporate Governance Terhadap Tax Aggressiveness. Seminar Nasional Dan The 3rd Call for Syariah Paper, (2012), 472-486.

Prastiwi, D. (2016). Mengenal Lebih Dekat Perpajakan Indonesia. Surabaya: Unesa University Press.

Prastiwi, D., \& Ratnasari, R. (2019). The Influence Of Thin Capitalization And The Executives ' Characteristics Toward Tax Avoidance By Manufacturers Registered On ISE In 2011-2015. AKRUAL: Jurnal Akuntansi, 10 (2)(April), 119-134.

Richardson, G., \& Lanis, R. (2007). Determinants of The Variability in Corporate Effective Tax Rates and Tax Reform: Evidence from Australia. Journal of Accounting and Public Policy, 26, 689-704. https://doi.org/10.1016/j.jaccpubpol.2007.10.003

Suandy, E. (2000). Hukum Pajak. Jakarta: Salemba Empat.

Suandy, E. (2006). Perencanaan Pajak (Edisi 3). Jakarta: Salemba Empat.

Suandy, E. (2017). Perencanaan Pajak. Jakarta: Salemba Empat.

Sudibyo, Y. A., \& Jianfu, S. (2016). Political Connections, State Owned Enterprises And Tax Avoidance: An Evidence From Indonesia. Corporate Ownership and Control, 13(January 2016), 279-283. https://doi.org/10.22495/cocv13i3c2p2

Sugiyono. (2016). Metode Penelitian Kuantitatif, Kualitatif, dan R\&D. Bandung: Alfabeta.

Tehupuring, R., \& Rossa, E. (2016). Pengaruh Koneksi Politik Dan Kualitas Audit Terhadap Praktik Penhindaran Pajak Di Lembaga Perbankan Yang Terdaftar Di Pasar Modal Indonesia Periode 2012-2014. Prosiding Seminar Nasional INDOCOMPAC, 366-376.

Zain, M. (2005). Manajemen Perpajakan (Kedua). Jakarta: Salemba Empat.

Zhang, H. (2012). How Does State Ownership Affect Tax Avoidance? Evidence from China. School of Accountancy, 13-18. 